胃切除後の縫合不全に続発したと考えられる孤立性脾膿晹の 1 例

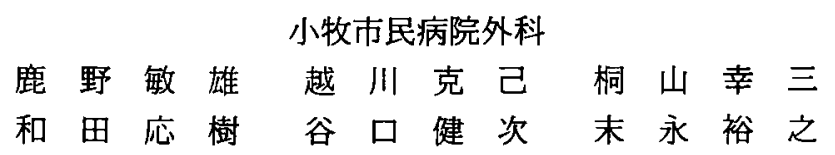

Billroth I 法再建後の早期残胃癌に対して2004年 4 月残胃全摘 Roux-Y 再建を施行 した。術後18日目，十二指腸断端の縫合不全から腹腔内膿瘍を形成，エコーガイド下穿 刺ドレナージ (以下, US下ドレナージと略記) を施行し速やかに軽快, 胃切除後45日目 に退院した。同年 7 月下旬に熱発で来院, CT 検查で孤立性脾膿瘍と䛦断した。脾膿瘍に 対してUS下ドレナージを施行, 速やかに解熱および炎症所見の消退, CT 検査でも膿湯 の縮小を認めた.US下ドレナージ後19日目にドレナージチューブを抜去した. 脾膿晹は 先行感染の消退後, 数力月してから発症することもあり, 患者が一旦回復した後の熱発 や腹痛に際しては脾膿瘍を念頭に置いて診療に当たることが重要である.

索引用語：孤立性脾膿惶, 縫合不全, 経皮的ドレナージ

\section{緒 言}

脾澧瘍は稀な疾患と考えられてきたが，画像診断技 術の進歩に伴い発見が容易となり我が国でも報告例が 増加している．原因となる感染源が特定できないこと や，培養検查によっても起炎菌が同定できないことも 多い. 今回，胃切除後腹腔内膿痬に続発した孤立性脾 膙煌に,エコーガイド下穿刺ドレナージ(以下, US下 ドレナージと略記）が有効であった症例を経験したの で報告する。

$$
\text { 症例 }
$$

患者：79歳, 男性.

主訴：熱発。

既往歴：20年前直腸癌で腹会陰式直腸切断術. 2003 年 7 月胃癌で幽門側胃切除, Billroth I 法再建, D2 郭 清 (Well differentiated tubular adenocarcinoma, Tl, N0, H0, P0, CY0, PM-, DM-, Stage I A, 根治度 $\mathrm{A}$ )。

現病歴 $1 ： 2004$ 年 1 月の上部消化管内視鏡検查で胃 切離線上に褐色調平坦隆起を認めた。生検の結果は well differentiated adenocarcinoma で, 再発が疑わ れるものの軽度の粘膜変化のみであり早期癌と考えら

2005 年 7 月 12 日受付 2005 年10月12日採用

〈所属施設住所〉

厂485-8520 小牧市常普請 $1-20$
れた，術前精査では胆石を認める以外には，肝臓リリ ンパ節などに転移を認めず，心荿超音波検査でも異常 を認めなかった. 2004年 4 月, 残胃全摘, Roux-Y 再 建, 胆震摘出術を施行, 肛門側は前回の吻合部よりも やや十二指腸側で切雕した。

病理組織学的検査: Well differentiated tubular adenocarcinoma, Tl, N0, H0, P0, CY0, PM-, DMー, Stage I A, 根治度 A であった.

術後経過：術後 3 日目で飲水，5 日目で食事開始， 7 日目の上部消化管造影検査では造影剤の遺漏は認め なかった，14日目頃から熱発があったため，18日目に 腹部 CT 検查を施行, 肝左葉背側に造影効果のない一 部 air density area を含む低吸収域を諮め, 肝左葉背 側に接する腹腔内膿瘍と考えられた(図 $1 \mathrm{a}$ ). 同日こ の腹腔内膿瘍に対してUS下ドレナージを施行し $7 \mathrm{Fr}$ pig tail カテーテルを留置した。内容は膿性であった。 $\mathrm{CPZ/SBT}$ を併用し翌日には解熱，その後の造影検査 で十二指腸断端から十二指腸が造影され，同部位の繾 合不全による腹腔内膿慯であると診断した(図 2 )。造 影模査で呩瘍腔は描出できないほどに縮小し炎症所見 も速やかに消退したため, その後のCT 検査は施行し なかった. CRP の陰転化を確認し US下ドレナージを 扱入後 20 日で抜去, その 6 日後に退院となった（図 3 a).

細菌培養検査：Streptococcus milleri, Enter- 


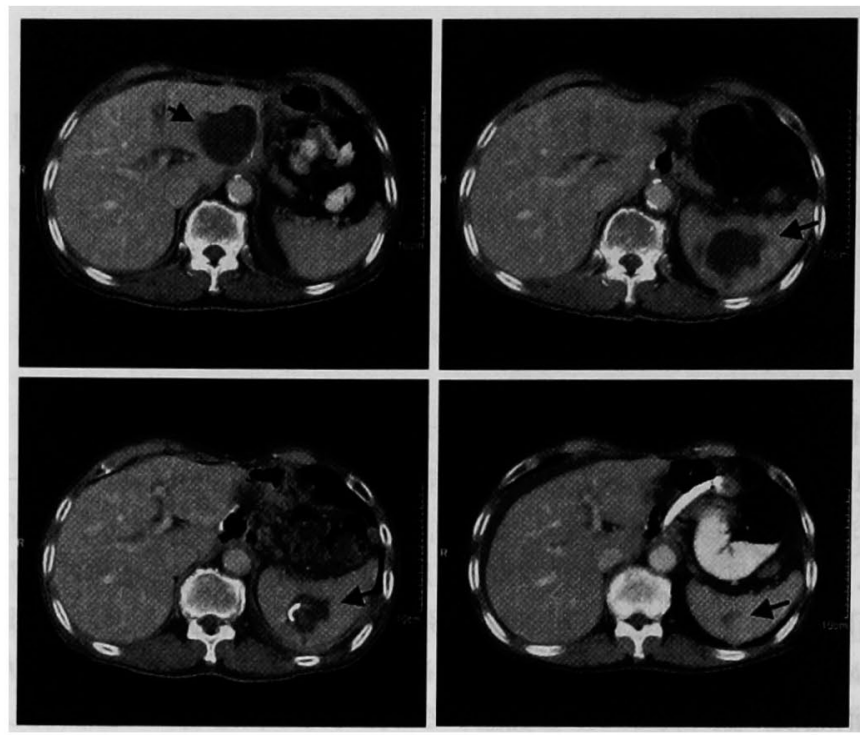

図 1 腹部造影 CT 検查：a）肝左葉背側に造影効果のない一部 air density area を含む低吸収域 (矢印)を認め，肝左葉背側に接する 腹腔内䐬瘍と考えられた。 b ) 脾荿に直径 $50 \mathrm{~mm}$ の境界明膫な造影 奻果を有しない low density area (矢印)を認め脾膿瘍と考えられ た. 肝左葉背側に異常は認めない. c) 腿瑒腔の縮小を認める (矢 印).d）脾葴にはごくかずかな low density area を認めるのみと なっている (矢印)。

$$
\begin{array}{l|l}
\mathbf{a} & \mathbf{b} \\
\hline \mathrm{c} & \mathbf{d}
\end{array}
$$

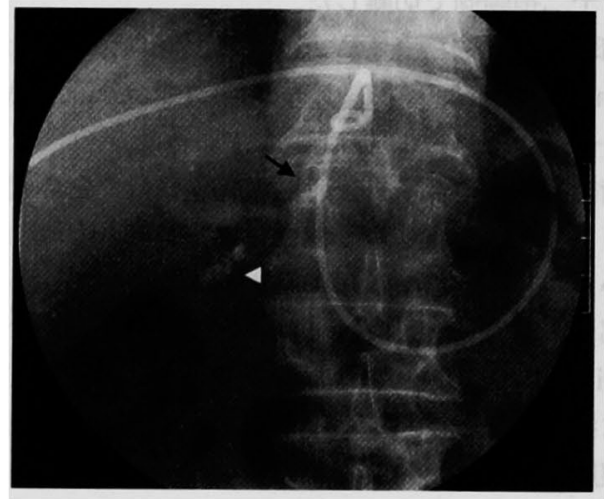

図 2 万う孔造影検査：十二指腸断端の staple line (矢印) から十二指腸内腔が造影され (印 頭), 十二指腸断端の縫合不全による腹腔内膿 瘍であったと推察された。

obacter aerogenes おょび Prevotella が検出された. $\mathrm{CPZ} / \mathrm{SBT}$ は 3 菌種ともに感受性を認めた。

現病歴 2 : 退院後, 発熱はなくまた無症状であった ため頻回の血液検査およびCT 検查は施行していなか ったが，前回の手術から 4 カ月近く経過した2004年 7
月下旬, 前日からの熱発を主訴に独歩にて来院した。

入院時現症: 体温は $38.5^{\circ} \mathrm{C}$, 右上腹部に軽度の圧痛 を認めるものの平坦, 軟であった。

入院時検查所見 (表 1 ): 白血球数 $12,500 / \mathrm{mm}^{3}$, $\mathrm{CRP} 15.8 \mathrm{mg} / \mathrm{dl}$ と高度炎症所見を認めた。

腹部 CT 検查 : 脾葴に直径 $50 \mathrm{~mm}$ の境界明瞕な low density area を認めた。肝左葉背側，十二指腸断端周 囲に異常は認めなかった（図 1 b).

以上より, 孤立性脾膿瘍と診断し, 同日 US 下ドレナ ージを施行した. $7 \mathrm{Fr}$ pig tail カテーテルを留置, 悪臭 強い乳白色脤が排出された。

細菌培養検查：Bacteroides が検出された。

経過：US 下ドレナージ翌日には解熱, 胸部単純 $\mathrm{X}$ 線検査で軽度の気胸と胸水を認めたが, 症状はなく胸 腔穿刺せずとも保存的に軽快した. ドレナージ後14日 目の腹部 CT 検查では膿場腔の縮小を認め（図 $1 \mathrm{c}$ ), CRP の陰転化を確認して, 19日目にドレナージチュー ブを报去，22日目に退院した（図 3 b ).

退院後は経過良好であったが2004年10月，腸閉塞と なり腹部 CT 検查を施行したところ，脾臓にはごくわ 
ずかな low density areaを認めるのみとなっており 脾膿瘍は治瘾したものと考えられた（図 $1 \mathbf{d}$ ). また， 腸閉塞については皎扼が疑われたため緊急手術を施 行, 術前診断通り腸切除を要した。

\section{考察}

脾膿眗は比較的稀な疾患とされており，欧米の剖検 例において0.14〜0.7\%と報告されている12). 脾膿場 の原因としては, (1) metastatic infection, (2) contigu-
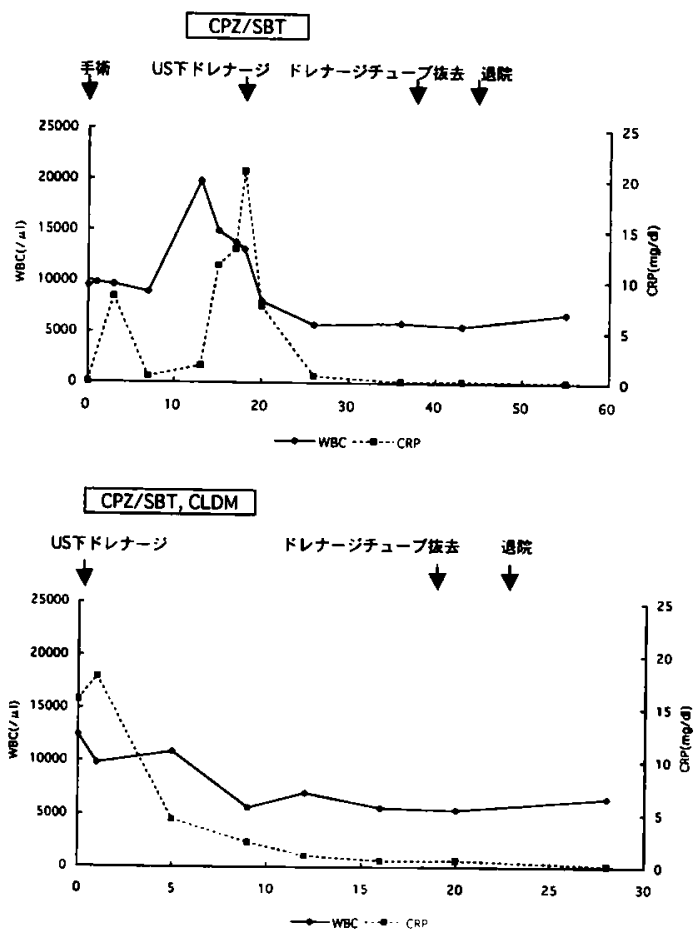

困 3 a 手術後治療経過：ドレナージ後炎症所見は速や かに消退した。

b 経皮的ドレナージ後治療経過：ドレナージ後炎 症所見は速やかに消退した。 ous infection, (3) infarction, (4) trauma, (5) immunodeficiency などが挙げられている ${ }^{3 / 4)}$. 近年, 抗生 物質の普及進歩により metastatic infection の症例が 劇的に減少している4). それに対し, 蔵器移植, 化学療 法, HIV 感染症, 糖尿病などの免疫能低下患者での報 告例が増加してきており，今後さらに増えていくもの と推察される．感染源としては細菌性心内膜炎が最も 多く，次いて尿路感染症が多いとされている5).しかし Picklemann $ら^{6)}$ は原発の感染が鎮静化し数週間から 数力月後に発症しうるため, 先行感染を証明するのは 困難であるとしている，自験例の場合は十二指腸断端 の縫合不全による腹腔内膿瑒に続発しており，手術侵

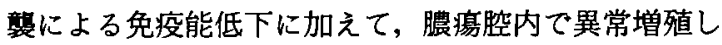
た細菌が門脈内に流入して血行性転移をきたし，脾膿 瘍を形成したと考えられる。細菌培責検查において起 炎菌の同定は保険診療上 3 菌種までしか認められてい ない.このため，自験例の腹腔内膿凚でも 3 菌種が同 定されているのみだが，嫌気性菌多菌種の混合感染で あり 4 菌種目以降の起炎菌として Bacteroides が存在 した可能性が高い. 腹腔内朖湟の US 下ドレナージを 施行した時点ですでに脾蔵には微小コロニーが形成さ れており，数力月の潜伏期間を経た後，脾膿崵として 発症した可能性がある。

脾膿瘍の主な治療としては, 抗生剂投与, 経皮的ド レナージおよび脾摘術が挙げられる。これまでは脾摘 術が治療の中心であったが, 脾摘に伴う免疫能の低下, 続発する重症敗血症および侵襲の大きさが短所として 挙げられる。それに代わって，画像診断の発達した近 年，経皮的ドレナージによる治撚報告例が増加してき ており，海外では脾膿湟に対する経皮的ドレナージの 有用性が早くから報告さ扎ている. Hadas-Halpren ら”は経皮的穿刺吸引または持続ドレナージを施行し 良好であったと報告しており，またChou ら膿痬径 によって超音波ガイド下穿刺吸引と持続ドレナージを

表 1 入院時血液検査所見

\begin{tabular}{lrrlrllr}
\hline WBC & 12,500 & $/ \mu 1$ & TP & 8.1 & $\mathrm{~g} / \mathrm{dl}$ & $\mathrm{Na}$ & $133 \mathrm{mEq} / \mathrm{l}$ \\
$\mathrm{RBC}$ & $445 \times 10^{4}$ & $/ \mu \mathrm{l}$ & Albmin & $3.8 \mathrm{~g} / \mathrm{dl}$ & $\mathrm{K}$ & $5.1 \mathrm{mEq} / \mathrm{l}$ \\
$\mathrm{Hb}$ & 13.8 & $\mathrm{~g} / \mathrm{dl}$ & Glucose & $112 \mathrm{mg} / \mathrm{dl}$ & $\mathrm{Cl}$ & $92 \mathrm{mEq} / 1$ \\
$\mathrm{Ht}$ & 40.6 & $\%$ & AST & $34 \mathrm{IU} / 1$ & $\mathrm{BUN}$ & $18.2 \mathrm{mg} / \mathrm{dl}$ \\
$\mathrm{Plt}$ & $29.4 \times 10^{4}$ & $/ \mu 1$ & ALT & $36 \mathrm{IU} / \mathrm{l}$ & $\mathrm{Cre}$ & $0.9 \mathrm{mg} / \mathrm{dl}$ \\
& & & T-Bil & $1.1 \mathrm{mg} / \mathrm{dl}$ & $\mathrm{CRP}$ & $15.8 \mathrm{mg} / \mathrm{dl}$ \\
$\mathrm{CEA}$ & $1.1 \mathrm{ng} / \mathrm{ml}$ & & & & & \\
$\mathrm{CA} 19-9$ & $6.4 \mathrm{U} / \mathrm{ml}$ & & & & & \\
\hline
\end{tabular}


使い分け，共に良好であったと報告している．経皮的 ドレナージは, 孤立性脾滕瘍の場合, 安全かつ低侵襲 に施行できるが，多発膿瘍の場合，十分なドレナージ が不可能であったり, 複数回の穿刺が必要となる。ま た解剖学的な脾臓の位置関係から, 経皮的ドレナーシ は経胸腔的穿刺となる危険性もある。より低侵襲な治 療として化学療法が挙げられ, 投与経路としては選択 的脾動脈内投与と全身投与の 2 通りがある. 選択的脾 動脈内投与のみで治療例も散見されるが9110), 現時 点では広く一般的に行われている治療てはなく, 侵襲 の点でも経皮的ドレナージに比し低いとは言い難い。 全身化学療法は最も低侵襲でかつ安全に施行でき, 全 身化学療法のみで治癒可能であったとの報告も認める ことから ${ }^{11121}$, 経皮的ドレナージの困難な多発小膙場 であればまず第一に施行するべき治療であると考えら れる。しかし，孤立性脾䐬湟の場合，入院経過中に膿 瘍が急速に增大し破裂した症例もあることから ${ }^{13}$, 膿 瘍径が大きく膿瘍壁が菲薄化し穿孔が瞕念される症例 に対しては，まず穿刺ドレナージなど外科的処置がふ さわしいと考えられる。

今回の症例は胃全摘後であり，瘑着のため脾摘術が 容易ではないと予湘できたこと，孤立性であったこと， 膿場径が大きく抗生剂投与のみでは効果が期待できな かったことなどから経皮的ドレナージによる治療を選 択した。気胸を併発し胸水も貯留したため, 慎重に経 過を観察したが，膿胸を併発したり，あらたに胸腔ド レナージを施行することなく保存的に軽快した。この ため胸水は脾臟内の膿崵ではなく, 胸壁または横隔膜 からの出血が胸腔内に貯留したものと考えられた。

また，経皮的ドレナージチューブの抜去時期である が, 体温, 白血球数や CRP など炎症所見の正常化を確 認してから行うのがよいと思われる。経皮的ドレナー ジ施行後 9 日目で抜去したところ膿湟が再然し, 再ド レナージも無効て脾摘を要した症例も報告されてお り ${ }^{14)}$, ドレナージチューブの抜去については慎重を要 する．われわれはドレナージチューブからの排液が僅 かとなっても, 少量の生理食塩水を注入, 吸引し閉塞 のないことを連日確認しつつ, CRP の陰転化を確認し た 7 日後, 経皮ドレナージ後19日目で抜去し良好な経 過を得た.ドレナージチューブの抜去時期については 何日目なら良いというものではく，膿場腔の大きさ や患者の全身状態を考慮して総合的に判断する必要が ある。

\section{結語}

胃切除後の縫合不全に続発したと考えられる孤立性 脾膘場の症例を経験した. 先行感染の後, 数力月後に 熱発や腹痛を認めた場合は, 脾晨瘍も念頭に置いた画 像診断を行う必要がある.

$$
\text { 文献 }
$$

1) Gadacz TR : Splenic abscess. World J Surg 9 : 410-415, 1985

2) Lauhorne TW, Zuidema GD: Splenic abscess. Surgery $79: 686-689,1976$

3) Chun $\mathrm{CH}$, Raff, MJ, Contreras L, et al : Splenic abscess. Medicine 59 : 50-65, 1980

4) Nelken N, Ignatius J, Skinner M, et al : Chang. ing clinical spectrum of splenic abscess. Am J Surg $154: 27-34,1987$

5) Cohen MAA, Galera MJ, Ruiz M, et al : Splenic abscess. Wold J Surg $14: 513-517,1990$

6) Picklemann JR, Paloyan E, Block GE: The surgical significance of splenic abscess. Surgery $68: 287-293,1970$

7) Hadas-Halpren I, Hiller N, Dolberg M, et al: Percutaneous drainage of splenic abscess : an effective and safe procedure. Br J Radiol 65 : 968-970, 1992

8) Chou YH, Tiu CM, Chiiou HJ, et al: Ultrasound-guided interventional procedures in splenic abscess. Eur J Radiol 28 : 167-170, 1998

9）岡本喜一郎, 藤田順子, 杉岡 䈆: 抗菌剤の選択 的脾動脈内注入療法が有効であった多発性脾㤟瑒 の 1 例. 日腹部救急医会誌 $18: 299-302,1998$

10）西森英史, 小林謙二, 福井里佳他: 抗生郕反復動 注療法が効した難治性脾膿瘍の1 例. 臨と研 $77: 337-339,2000$

11）杉浦晋平, 石岡淳一郎, 千㷊喜美男他：滕腎症加 ら進展した脾晨瑒の 1 例. 泌紀 $50 ： 265-267$ ， 2004

12）木山輝郎, 田尻 孝, 吉行俊郎地：穿孔性胃潰瘍 による腹膜炎術後に発症した孤立性脾滕場の 1 例. 日臨外会誌 $64: 3148-3151,2003$

13）谷掛雅人, 仲本 剛, 新保雅也他：単発性脾脤愓 の 1 例。臨外 $53: 265-269,1998$

14）大塚由一朗, 金子弘真, 吉野正晃他: 経皮的ドレ ナージ後, 脾摘術を要した孤立性脾膿瘍の 1 例。 日外科系連会誌 $28 ： 809-813,2003$ 


\title{
A CASE OF A SOLITARY SPLENIC ABSCESS SECONDARY TO SUTURE FAILURE AFTER GASTRECTOMY
}

\author{
Toshio SHIKANO, Katsumi KOSHIKAWA, Kozo KIRIYAMA, \\ Masaki WADA, Kenji TANIGUCHI and Hiroyuki SUENAGA \\ Department of Surgery, Komaki Municipal Hospital
}

The patient was a 79-year-old man who had undergone distal gastrectomy with Billroth I reconstruction for gastric cancer. Early cancer of the gastric remnant developed, and total extirpation of the remnant stomach with Roux-Y reconstruction was performed in April 2004. On the day 18 after the operation, an intraabdominal abscess was detected secondary to suture failure at the stump of the duodenum. Puncture drainage was performed under ultrasonographic guidance. The patient was discharged from the hospital very much improved on the day 45 after the operation. In late July, he visited the hospital because of fever and was diagnosed as having a solitary splenic abscess on an abdominal CT scan. Puncture drainage under the ultrasonographic guidance. To treat the abscess, resulted in prompt resolution of fever as well as inflammatory findings. Abdominal CT scan also demonstrated a reduction of the abscess. On the day 19 after the puncture drainage, the drainage tube was removed. Since a splenic abscess may develop several months after resolution of the initial infection, symptoms such as fever and abdominal pain after apparent remission should be treated in consideration of a possible splenic abscess. 